\title{
Effect of Feeding Rate and Diet Oil Source on Growth Performance and Feed Utilization of Rabbitfish (Siganus rivulatus) Fry
}

\author{
Ragab A Mohammed1*, Mohamed FA Abdel-Aziz1, Ramadan M Abou-Zied2, Sobhy M Allam2 \\ ${ }^{1}$ National Institute of Oceanography and Fisheries (NIOF), Egypt \\ ${ }^{2}$ Animal Production Department, Faculty of Agriculture, Fayoum University, Egypt
}

"Corresponding author: Ragab A Mohammed, National Institute of Oceanography and Fisheries (NIOF), Egypt. Email: Ragab_ nashy@yahoo.com

Citation: Mohammed RA, Abdel-Aziz MFA, Abou-Zied RM, Allam SM (2017) Effect of Feeding Rate and Diet Oil Source on Growth Performance and Feed Utilization of Rabbitfish (Siganus rivulatus) Fry. J Fish Aqua Dev: JFAD-123. DOI:10.29011/JFAD$123 / 100023$

Received Date: 6 September, 2017; Accepted Date: 13 September, 2017; Published Date: 21 September, 2017

\begin{abstract}
This study was conducted to determine the optimum feeding rate and evaluate the total replacement of fish oil as main source of fat by linseed oil from diet on growth performance and feed utilization of rabbitfish fry. This trial was factorial ( $3 \times 2)$ and continued for 114 days. The average initial weight (W1) of fry was $0.18 \pm 0.012 \mathrm{~g}$ and the average initial length (L2) was 2.76 $\mathrm{cm} \pm 0.05$. This trial tested two factors, the feeding rate (5\%,7\% and $9 \%$ of fish body weight) with two diets $(36.44 \% \mathrm{CP})$ differed in oil source (diet A contained fish oil) and (diet B contained linseed oil). The stocking density was 40 fish per m3; fry was fed twice daily at $9 \mathrm{am}$ and $4 \mathrm{pm}$. The results cleared that, insignificant differences between the different of feeding rates which used in this trial regardless the diet oil source, on the other hand, the growth parameters values increased with increasing the feeding rate and the diet which contained fish oil was the best in the growth parameters compared with the other which contained linseed oil. The growth performance parameters were significantly affected by interaction between feeding rate and oil diet source. Whereas, the fish fed at the diet (A) with 9\% feeding rate was obtained the highest final weight (W2), Total Gain (TG), Relative Growth Rate (RGR), and Specific Growth Rate (SGR) in all the treatments. The feed utilization parameters were significantly affected by the feeding rates regardless of diet oil source. The best Feed Conversion Ratio (FCR) was recorded by the fish fed at 5\% feeding rate, the statistical analysis did not show any significant differences between the fish fed at the diet (A) and diet (B) in all the feed utilization parameters. Also, the interaction between feeding rate and diet oil source on feed utilization of rabbitfish fry appeared significant differences in all the treatments. The best FCR value was achieved with was fish fed on the diet (B) and (A) at feeding rate $5 \%$.
\end{abstract}

Keywords: Fish oil; Feeding rate; Feed utilization; Growth parameters; Rabbitfish; Total replacement

\section{Introduction}

Rabbitfishes belong to the genus Siganus of the family siganidae [1]. Siganids are herbivorous marine and brackish water fishes that are found throughout the indo west pacific [2], and the more common species are the objects of traditional subsistence and commercial fisheries throughout this region. There has been interest in the culture of these fishes in ponds or cages in several areas [3].

Rabbitfish high tolerances to environmental factors, tolerance to rough handing and crowding so can be stocked at very high density [4]. Rabbitfish are considered to be excellent food fish in many parts of the world especially in the eastern Mediterranean and indo-pacific regions [5] and are economically important and relatively easy to rear and thus considered suitable for aquaculture [6]. Additionally, rabbitfish have a high market value in Eastern Mediterranean countries [7], invaded the eastern Mediterranean via Suez Canal. The optimal feeding rate is the most important factor in the success of any aquaculture practice because overfeeding or underfeeding leads to increased disease, resulting in higher mortality [8]. By controlling the feeding rates, farmers can successfully reduce cost; maximize growth whilst managing other factors such as individual size variation and water quality which are considered important in rearing of fish in culture conditions [9]. Knowledge about optimum feeding levels is important not only for promot- 


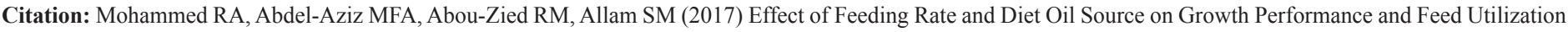
of Rabbitfish (Siganus rivulatus) Fry. J Fish Aqua Dev: JFAD-123.

ing good growth and feed efficiency, but also for preventing water quality deterioration as the result of excess feeding and enhancing economic viability of aquaculture processing [10]. Several factors influence the feeding rate in aquaculture system. These include fish size, species and rearing systems [11]. In addition, feeding rate is influenced by the presence of the nutrients in the feed [12].

Besides, the total replacement of fish oil as main source of fat with plant oils on growth and feed utilization of rabbitfish fry. The higher prices and uncertainty of availability of Fish Oil (FO). So, the much attention has been focused on vegetable oils, which have lower price and larger production volume than FO [13] and a number of studies have shown that plant oils could replace substantial levels of FO without affecting the survival and growth of fishes [14] and [15]. Moreover, [16] demonstrated that up to $90 \%$ of dietary fish oil can be replaced by vegetable (palm) oils without compromising growth or feed utilization of some fish species such as Clarias gariepinus and Mystus nemurus. [17] reported that, in rainbow trout up to $80-90 \%$ of vegetable oils (e.g., soybean; rapeseed; olive; and palm oils) can be used without compromising their growth. In relation to fish requirement of fatty acids, the marine fish species generally have only $\omega-3$ PUFA which originate from marine phytoplankton. However, there are several marine species whose lipids contain comparatively high levels of $\omega-6$ PUFA. Generally, it is known that, $\omega-3$ PUFA are required by all marine fishes including subtropical fish species [18].

Consideration of a few of the studies which were conducted on siganidae, So the present study aimed to determine the best feeding rate and evaluate the total replacement of fish oil as main source of fat with plant oils from diet on growth and feed utilization of rabbitfish fry.

\section{Materials and Methods}

The present study was conducted using the research facilities of Shakshouk Fish Research Station, Fayoum Governorate, National Institute of Oceanography and Fisheries (NIOF), Egypt. Rabbitfish (Siganus rivulatus) fry were obtained from (Mediterranean Sea) National Institute of Oceanography and Fisheries (NIOF), Alexandria Governorate-Egypt, initial average weight for this fry was $0.18 \mathrm{~g} \pm 0.012$ (SE Standard Error) and initial average length was $2.76 \mathrm{~cm} \pm 0.057$.

\section{Fish acclimatization}

The fish were acclimatized to water condition Lake Qaroun (33 part per thousand, ppt). Fish were acclimatized for one week before size sorting and removing of large and small fish.

\section{Diet preparation}

Two artificial diets A and B were formulated to have fish or linseed oils as fat sources, with about $36 \%$ crude protein for each (Table, 1). Fatty acids compositions of artificial feed were shown in (Table 2). (Table 1). Ingredients and a proximate chemi$\mathrm{cal}$ analysis of the experimental diets (A and B).

\begin{tabular}{|c|c|c|}
\hline Ingredients $(\mathrm{g} / 100 \mathrm{~g})$ & $\operatorname{Diet}(\mathrm{A})$ & Diet (B) \\
\hline Fish meal $(72 \% \mathrm{CP})$ & 22 & 22 \\
\hline $\begin{array}{l}\text { Extruded full fat Soybean meal } \\
\qquad(37 \% \mathrm{CP})\end{array}$ & 43 & 43 \\
\hline Wheat bran fine & 28 & 28 \\
\hline Fish oil & 4 & - \\
\hline Linseed oil & - & 4 \\
\hline Super yeast & 1 & 1 \\
\hline Starch & 1.7 & 1.7 \\
\hline Vit. \& Min. \& premix & 0.3 & 0.3 \\
\hline Total & 100 & 100 \\
\hline \multicolumn{3}{|c|}{ Chemical analysis \% on Dry matter basis } \\
\hline \multicolumn{2}{|l|}{ Moisture (M) } & 6.94 \\
\hline \multicolumn{2}{|c|}{ Dry matter (DM) } & 93.06 \\
\hline \multicolumn{2}{|c|}{ Crude protein $(\mathrm{CP})$} & 36.44 \\
\hline \multicolumn{2}{|c|}{ Ether extract (EE) } & 13.78 \\
\hline \multicolumn{2}{|c|}{ Crude fiber (CF) } & 3.10 \\
\hline \multicolumn{2}{|c|}{ Nitrogen free extract (NFE) } & 39.02 \\
\hline \multicolumn{2}{|l|}{ Ash } & 7.66 \\
\hline \multicolumn{2}{|c|}{ Gross energy (GE, Kcal/g)* } & 5.09 \\
\hline \multicolumn{3}{|c|}{$\begin{array}{c}\text { Notice: Chemical analysis was determined according to (A.O.A.C } \\
\text { 1984) [19] and NFE was calculated by difference. } \\
\text { Calculated according to NRC (1993) [20]. }\end{array}$} \\
\hline
\end{tabular}

Table 1: Ingredients and a proximate chemical analysis of the experimental diets (A and $\mathrm{B})$.

\begin{tabular}{|c|c|c|}
\hline \multirow{2}{*}{ Fatty acid } & \multicolumn{2}{|c|}{ Diets } \\
\hline & $\mathbf{A}$ & B \\
\hline C14:0 Myristic acid & 1.90 & 0.80 \\
\hline C16:0 Palmatic acid & 15.70 & 8.58 \\
\hline C18:0 Stearic acid & 3.70 & 4.35 \\
\hline C20:0 Arachidic acid & ND & 1.07 \\
\hline$\sum \mathrm{SFA}$ & 21.30 & 14.80 \\
\hline C15:1 Pentadecnoic acid & $\mathrm{ND}$ & ND \\
\hline C16:1 Palmatioleic acid & 5.60 & 1.50 \\
\hline 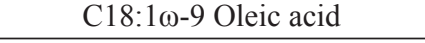 & 17.32 & 21.70 \\
\hline C20:1 $\omega-9$ (Eicosenoic acid) & 1.20 & 0.55 \\
\hline C22:1 $\omega-9$ (Erucic acid) & ND & 0.24 \\
\hline$\sum$ MUFA & 24.12 & 23.65 \\
\hline 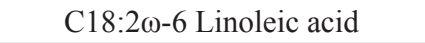 & 4.30 & 38.63 \\
\hline 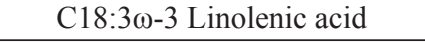 & ND & 15.22 \\
\hline 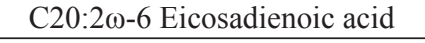 & 3.18 & 0.31 \\
\hline 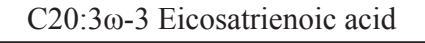 & 1.52 & 0.57 \\
\hline 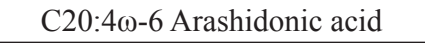 & 3.97 & 4.08 \\
\hline C20:5 $\omega-3$ Eicosapentaenoic acid & 10.79 & ND \\
\hline C22:2 Docosadienoic acid & 3.15 & 2.10 \\
\hline 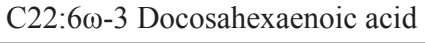 & 27.00 & ND \\
\hline
\end{tabular}




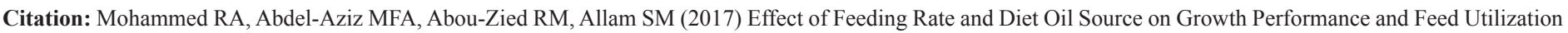
of Rabbitfish (Siganus rivulatus) Fry. J Fish Aqua Dev: JFAD-123.

\begin{tabular}{|c|c|c|}
\hline$\sum$ PUFA & 53.91 & 61.18 \\
\hline Unidentified & 0.67 & 0.64 \\
\hline$\sum \omega-3$ & 39.31 & 15.79 \\
\hline$\sum \omega-6$ & 11.45 & 43.02 \\
\hline$\sum \omega-3 / \sum \omega-6$ & 3.43 & 0.37 \\
\hline
\end{tabular}

Notice: ND: not detected $\sum$ SFA: sum saturated fatty acid, $\sum$ MUFA: sum monounsaturated fatty acid, $\sum$ PUFA: sum polyunsaturated fatty acid, $\sum \omega-3$ : sum omega three and $\sum \omega-6$ : sum omega six.

Table 2: Fatty acids composition (\% of total fatty acid) of the experimental diets.

\section{Experimental Ponds}

This trial was carried out in twelve concrete ponds. The dimensions of each pond were $2 \mathrm{~m}$ length, $2 \mathrm{~m}$ width and $1 \mathrm{~m}$ height and the water volume of each pond was $3 \mathrm{~m}^{3}$.

\section{Trial Design and Distribution of Fish in Ponds}

This trial consisted of two factors, the first factor was feeding rate $(5 \%, 7 \%$ and $9 \%$ of fish body weight) with two diets $(36.44 \%$ $\mathrm{CP}$ ) differ in source oil (diet A contained fish oil as main source of fat while diet B contained linseed oil as main source of fat. The stocking density was 40 fish per $\mathrm{m}^{3}$ (120 fish per each pond) the water exchange rate was $35 \%$ of water volume in each pond every two days and the feeding was twice daily at 9 am and 4 pm.

\section{Running Water System in Experimental Units (Tanks)}

The system contained on water pump, sand filter unit and two large tanks (10000 liter/tank) used to storage the water at a point between the water source (Lake Qaroun water) and experimental units. The water pump was raising the water from water source to the sand filter unit then to the large tanks and hence to experimental units.

\section{Aeration System of Experimental Units (Tanks)}

The system contained on air pump or blower connected to a network of plastic pipes this pipes transport the air to each experimental unit, the air was controlled by tap of each pond and the air diffusers was used to distribute of air in all experimental unit trends.

\section{Water Quality}

Some water quality parameters were measured of each treatment. Temperature, $\mathrm{pH}$, salinity and $\mathrm{EC}$ were measured daily at 1pm, Dissolved Oxygen (DO) was measured every week. Nitrite, nitrate, total ammonia was measured every two weeks. by centigrade thermometer, Orion digital $\mathrm{pH}$ meter model 201, Refractometer (VITAL Sine SR-6, China), Conductivity meter model (YSI.SCT-33) and oxygen meter (Cole Parmer model 5946) respectively. While nitrite, nitrate, total ammonia was measured by the chemical methods according to [21, 22].

\section{Measurements of Growth Performance and some of the Internal Organs}

Total weight Gain (TG), Average Daily Gain (ADG), Relative Growth Rate (RGR), Specific Growth Rate (SGR), Survival Rate (SR), Hepatosomatic Index (HSI) and Viscerosomatic Index (VSI).

\section{These Parameters Were Calculated According the Fol- lowing Equations}

$\mathrm{TG}, \mathrm{g}=$ final weight $\left(\mathrm{W}_{2}\right)$-initial weight $\left(\mathrm{W}_{1}\right), \mathrm{ADG}, \mathrm{g} /$ day $=$ average weight gain, $\mathrm{g}$ / experimental period, day, $\mathrm{RGR}, \%=\left[\left(\mathrm{W}_{2}\right.\right.$ $\left.-\mathrm{W}_{1)} / \mathrm{W}_{1}\right] \times 100, \mathrm{SGR}, \% /$ day $=\left[\left(\ln \mathrm{W}_{2}-\ln \mathrm{W}_{1}\right) / \mathrm{t}\right] \times 100$ whereas $\mathrm{ln}$ : is the natural $\log$. and $\mathrm{t}$ : is the time in days, $\mathrm{SR} \%=($ Number of fish at end/ Number of fish at start) $\times 100$, (HSI, \%) $=($ liver weight/body weight $) \times 100$ and $($ VSI, $\%)=($ weight of viscera and associated fat tissue/body weight) $\times 100$.

\section{Measurements of Feed Utilization Efficiency}

Feed Intake g/ fish (FI), Feed Conversion Ratio (FCR), Feed Conversion Efficiency (FCE), Protein Efficiency Ratio (PER), Protein Productive Value (PPV), Energy Efficiency Ratio (EER), Energy Productive Value (EPV) and Lipid Retention (LR).

\section{These parameters were calculated according the follow-} ing equations:

FI, $g$ /fish feed intake during the trial period/ the final number of fish for this trial, FCR = feed intake, g / weight gain, g., FCE, $\%=($ weight gain, g./ feed intake, $g) \times 100, P E R=$ Weight gain, $g /$ Protein intake, g., PPV, \% = (Retained protein, g/ Protein intake, g) $\times 100$, EER $=$ Weight gain, g/ Energy intake, Kcal, EPV, $\%=$ (Retained Energy, Kcal/ Energy intake, Kcal $) \times 100$, LR, \% $=($ Retained lipid, g/ lipid intake, g) $\times 100$.

\section{Chemical analysis of feeds and whole fish body}

The chemical analysis of diet and whole body fish samples were carried out as described by (A.O.A.C, 1984) [19] and Gross Energy (GE) was estimated for formulated diets the factors 5.64, 9.44 and $4.11 \mathrm{Kcal} / \mathrm{g}$ for CP, EE and carbohydrates, respectively, were used [20], for fish 5.5 and $9.5 \mathrm{Kcal} / \mathrm{g}$ for protein and fat respectively [23].

\section{Fatty acid analysis and Gas Chromatography (GC) Con- ditions}

Lipid extraction was carried out according to [24]. Preparation of fatty acid methyl ester was carried out according to Jumat et al. (2006) [25] and Siew et al. (1995) [26]. The fatty acid composition of oils was determined using its fatty acid methyl esters and was injected into gas-chromatography for analysis. The identification of the peaks was carried out by retention times [27]. 


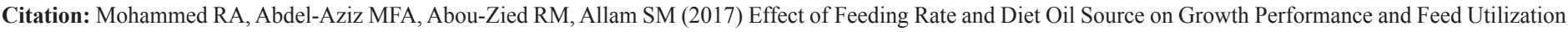
of Rabbitfish (Siganus rivulatus) Fry. J Fish Aqua Dev: JFAD-123.

\section{Gas Chromatography (GC) Conditions}

Device Model :HP (Hewlett Packard) 6890GC, Detectore: FID( Flame Ionization Detector), detectore temperature $240^{\circ} \mathrm{C}$, injector temperature $220^{\circ} \mathrm{C}$, Injection volume $3 \mu \mathrm{l}$, Split ratio 50:1, column: DB-23 (50\%-Cyanopropyl-methylpolysiloxane), 30, 0.32 mm ID, $0.25 \mu \mathrm{m}$ film thickness. Carrier gas: Nitrogen, gas flow: $1 \mathrm{ml} / \mathrm{min}$. Oven program: Initial temperature $140^{\circ} \mathrm{C}$ for $5 \mathrm{~min}$, Ramps 1 , Rate ${ }^{\circ} \mathrm{C} /$ $\min 4$ and final temperature $240^{\circ} \mathrm{C}$.

\section{Statistical Analysis}

The data were analyzed by general linear model and significant differences were determined by Duncan waller Multiple Range Test at 5\% level using SPSS Statistical Package Program (SPSS, 2007) [28] SPSS Inc. Released 2007. SPSS for Windows, Version 16.0 .

\section{Results and Discussion}

\section{Water Quality}

Water quality parameters in this trial were shown in (Table 3). These results cleared that, increase of feeding rate lead to increase of nitrite, nitrate, and ammonia concentration. However, the averages of water temperature, $\mathrm{pH}$, water salinity, Electrical Conductivity (EC), Dissolved Oxygen (DO), nitrite, nitrate and total ammonia values in all treatments were within the acceptable limits for rabbitfish (Siganus rivulatus) fry as reported by (Westernhagen and [29], Huguenin and Colt, 1989 [30], Meade, 1989 [31], Davis, 1993 [32], Lawson, 1995 [33], ANZECC, 2000 '[34], EPA, 2003 [35], Saoud et al., 2007b [36] and Saoud et al., 2008) [37]. It can be said that, the water quality was not affected by feeding rate and dietary oil sources.

\begin{tabular}{|c|c|c|c|c|c|c|}
\hline \multirow{3}{*}{ Items } & \multicolumn{6}{|c|}{ Treatments } \\
\hline & \multicolumn{3}{|c|}{ Diet (A) Fish oil } & \multicolumn{3}{|c|}{ Diet (B) Linseed oil } \\
\hline & (A1) $5 \%$ & (A2) $7 \%$ & (A3) $9 \%$ & (B1) $5 \%$ & (B2) $7 \%$ & (B3) $9 \%$ \\
\hline Temperature $\left({ }^{\circ} \mathrm{C}\right)$ & $26.507 \pm 0.261$ & $26.428 \pm 0.252$ & $26.440 \pm 0.241$ & $26.524 \pm 0.277$ & $26.387 \pm 0.258$ & $26.375 \pm 0.255$ \\
\hline $\mathrm{pH}$ & $8.411 \pm 0.052$ & $8.365 \pm 0.069$ & $8.310 \pm 0.072$ & $8.360 \pm 0.097$ & $8.334 \pm 0.080$ & $8.373 \pm 0.069$ \\
\hline Salinity $\%$ & $33.410 \pm 0.100$ & $33.420 \pm 0.110$ & $33.333 \pm 0.167$ & $33.46 \pm 0.150$ & $33.440 \pm 0.121$ & $33.455 \pm 0.100$ \\
\hline $\mathrm{EC} \mathrm{mS} / \mathrm{cm}^{*}$ & $47.100 \pm 1.00$ & $47.100 \pm 0.500$ & $46.400 \pm 0.400$ & $47.200 \pm 0.800$ & $47.200 \pm 0.200$ & $47.100 \pm 0.200$ \\
\hline $\mathrm{DO} \mathrm{mg} / \mathrm{l}$ & $7.265 \pm 0.335$ & $7.065 \pm 0.435$ & $6.295 \pm 1.105$ & $6.495 \pm 0.705$ & $6.920 \pm 0.780$ & $6.435 \pm 0.535$ \\
\hline Nitrite, $\mathrm{mg} / 1$ & $0.036 \pm 0.017$ & $0.088 \pm 0.031$ & $0.066 \pm 0.002$ & $0.037 \pm 0.017$ & $0.025 \pm 0.012$ & $0.080 \pm 0.026$ \\
\hline Nitrate, mg/1 & $0.102 \pm 0.026$ & $0.183 \pm 0.052$ & $0.160 \pm 0.057$ & $0.110 \pm 0.028$ & $0.105 \pm 0.039$ & $0.178 \pm 0.027$ \\
\hline $\begin{array}{c}\text { Total ammonia, } \\
\mathrm{mg} / \mathrm{l}\end{array}$ & $0.252 \pm 0.018$ & $0.300 \pm 0.013$ & $0.417 \pm 0.003$ & $0.283 \pm 0.044$ & $0.349 \pm 0.013$ & $0.390 \pm 0.010$ \\
\hline
\end{tabular}

Table 3: Mean $( \pm \mathrm{SE})$ of water quality parameters

\section{Growth performance}

\section{Effect of Feeding Rate On Growth Performance of Rabbitfish (Siganus rivulatus) Fry Regardless the Diet Oil Source.}

As shown in (Table 4) The results showed that, insignificant differences at level $(p \leq 0.05)$ were obtained by feeding rate in the final weight $\left(\mathrm{W}_{2}\right.$ ), Total Weight Gain (TG), Average Daily Gain (ADG), Relative Growth Rate (RGR), Specific Growth Rate (SGR) and Survival Rate (SR). In relation to, some of the internal organs parameters, no significant differences between treatments in Hepatosomatic Index (HSI) but Viscerosomatic Index (VSI) was significantly differed between the treatments and both the second and the third treatment was higher in (VSI) value than the first treatment.

The growth parameters values increased with increasing the feeding rate, this agree with results of other studies are different in various species. Studies with several fish species have revealed that with increasing feeding rate, the growth increases at higher ration levels and decreases at lower ration levels [12]. Who reported the highest specific growth rate was obtained in the fry of silver dollar [38], Metynnis schreitmulleri fed at 9\% body weight per day. And [39] stated that, increasing feeding rate increases the availability of 


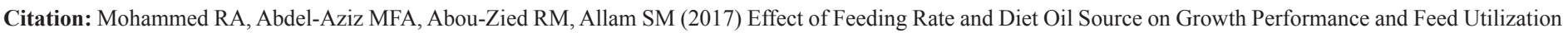
of Rabbitfish (Siganus rivulatus) Fry. J Fish Aqua Dev: JFAD-123.

resources (e.g., amino acids, structural lipids, energy) for growth, and weight gain is typically greater among fish at higher feeding rates. Shamoushaki et al. (2012) [40] found that, the highest growth was obtained with Rutilus frisii Kutum fish fed 10\% BW/day. Also in the same trend, studies on other fish such as Mystus nemurus [10] Dicentrarchus labrax [42] showed that, feeding rate with 10\% BW /day fish growth was better.

\begin{tabular}{|c|c|c|c|c|c|c|c|c|c|c|}
\hline Items \& Treatments & $\mathbf{W}_{1}, \mathrm{~g}$ & $\mathbf{L}_{2}, \mathbf{c m}$ & $\mathbf{W}_{2}, \mathbf{g}$ & TG, $\mathrm{g}$ & ADG, g/day & RGR, \% & $\begin{array}{c}\text { SGR/day, } \\
\%\end{array}$ & $\mathrm{SR}, \%$ & $\begin{array}{c}\text { HSI, } \\
\%\end{array}$ & VSI, \% \\
\hline \multicolumn{11}{|c|}{ Effect of feeding rate regardless the diet oil source } \\
\hline Feeding rate $5 \%$ & 0.18 & 6.86 & 4.33 & 4.15 & 0.036 & 2306.93 & 2.79 & 41.87 & 3.31 & $24.33^{\mathrm{b}}$ \\
\hline Feeding rate $7 \%$ & 0.18 & 6.88 & 5.28 & 5.10 & 0.045 & 2837.49 & 2.96 & 39.58 & 2.89 & $28.48^{\mathrm{a}}$ \\
\hline Feeding rate $9 \%$ & 0.18 & 7.25 & 5.61 & 5.43 & 0.048 & 3016.66 & 3.00 & 44.37 & 3.50 & $27.56^{\mathrm{a}}$ \\
\hline $\mathrm{SED}^{*}$ & - & 0.340 & 0.720 & 0.640 & 0.005 & 355.330 & 0.109 & 4.570 & 0.386 & 0.750 \\
\hline \multicolumn{11}{|c|}{ Effect of diet oil source regardless the feeding rate } \\
\hline Diet (A) Fish oil & 0.18 & $7.38^{\mathrm{a}}$ & $5.69^{\mathrm{a}}$ & $5.51^{\mathrm{a}}$ & $0.048^{\mathrm{a}}$ & $3061.10^{\mathrm{a}}$ & $3.03^{\mathrm{a}}$ & 41.24 & 3.02 & 26.33 \\
\hline Diet (B) Linseed oil & 0.18 & $6.61^{\mathrm{b}}$ & $4.46^{\mathrm{b}}$ & $4.28^{\mathrm{b}}$ & $0.037^{\mathrm{b}}$ & $2379.60^{b}$ & $2.82^{b}$ & 42.63 & 3.45 & 27.24 \\
\hline $\mathrm{SED}^{*}$ & - & 0.155 & 0.528 & 0.461 & 0.004 & 256.200 & 0.079 & 3.720 & 0.311 & 1.235 \\
\hline \multicolumn{11}{|c|}{ Effect of interaction between feeding rate and diet oil source } \\
\hline $\begin{array}{c}\text { Diet (A) \& Feeding rate } 5 \% \\
\text { (A1) }\end{array}$ & 0.18 & $7.19^{\mathrm{ab}}$ & $4.99^{\mathrm{ab}}$ & $4.81^{\mathrm{abc}}$ & $0.042^{\mathrm{abc}}$ & $2675.00^{\mathrm{abc}}$ & $2.90^{\mathrm{ab}}$ & 37.08 & $3.52^{\mathrm{ab}}$ & $23.96^{\mathrm{b}}$ \\
\hline $\begin{array}{c}\text { Diet (A) \& Feeding rate } 7 \% \\
\text { (A2) }\end{array}$ & 0.18 & $7.28^{\mathrm{ab}}$ & $5.57^{\mathrm{ab}}$ & $5.39^{\mathrm{ab}}$ & $0.047^{\mathrm{ab}}$ & $2997.22^{\mathrm{ab}}$ & $3.00^{\mathrm{ab}}$ & 44.16 & $2.44^{\mathrm{b}}$ & $27.51^{\mathrm{a}}$ \\
\hline $\begin{array}{c}\text { Diet (A) \& Feeding rate } 9 \% \\
\text { (A3) }\end{array}$ & 0.18 & $7.66^{\mathrm{a}}$ & $6.50^{\mathrm{a}}$ & $6.32^{\mathrm{a}}$ & $0.055^{\mathrm{a}}$ & $3511.10^{\mathrm{a}}$ & $3.14^{\mathrm{a}}$ & 42.50 & $3.09^{\mathrm{ab}}$ & $27.53^{\mathrm{a}}$ \\
\hline $\begin{array}{l}\text { Diet (B) \& Feeding rate } 5 \% \\
\text { (B1) }\end{array}$ & 0.18 & $6.53^{\mathrm{c}}$ & $3.67^{\mathrm{b}}$ & $3.49^{\mathrm{c}}$ & $0.030^{\mathrm{c}}$ & $1938.88^{c}$ & $2.64^{\mathrm{c}}$ & 46.66 & $3.10^{\mathrm{ab}}$ & $24.70^{\mathrm{b}}$ \\
\hline $\begin{array}{c}\text { Diet (B) \& Feeding rate } 7 \% \\
\text { (B2) }\end{array}$ & 0.18 & $6.48^{c}$ & $5.00^{\mathrm{ab}}$ & $4.82^{\mathrm{abc}}$ & $0.042^{\mathrm{abc}}$ & $2677.77^{\mathrm{abc}}$ & $2.91^{\mathrm{ab}}$ & 35.00 & $3.43^{\mathrm{ab}}$ & $29.45^{\mathrm{a}}$ \\
\hline $\begin{array}{l}\text { Diet (B) \& Feeding rate } 9 \% \\
\text { (B3) }\end{array}$ & 0.18 & $6.85^{\mathrm{bc}}$ & $4.72^{\mathrm{ab}}$ & $4.54^{\mathrm{bc}}$ & $0.039^{\mathrm{bc}}$ & $2522.22^{\mathrm{bc}}$ & $2.85^{\mathrm{bc}}$ & 46.25 & $3.91^{\mathrm{a}}$ & $27.59^{\mathrm{a}}$ \\
\hline SED $^{*}$ & - & 0.230 & 0.827 & 0.593 & 0.005 & 329.360 & 0.094 & 5.58 & 0.415 & 1.000 \\
\hline \multicolumn{11}{|c|}{$(a, b$ and $c)$ Average in the same column having different superscripts significantly different at $(\mathrm{P} \leq 0.05)$. } \\
\hline
\end{tabular}

Table 4: Effect of feeding rate and the diet oil source on growth performance of rabbitfish (Siganus rivulatus) fry.

Moreover, Silva et al. (2007) [42] showed that, increasing feeding rate on Colossoma macropomum with $10 \% \mathrm{BW}$ /day is more growth.

On the other hand, (Table 4) showed that, the growth performance and survival rate were not significantly affected by the different feeding rates. Hence, it can be said that, the lowest of feeding rate ( $5 \%$ of body weight) is better than $7 \%$ and $9 \%$ feeding rate in terms of reducing of feed offered per fish. This lead to reducing of the cost production. Moreover, many studies were conducted to evaluate the optimum feeding rate and agreed with our results such as Deyab and Hussein (2015) [43] who reported that, feeding rate of $5 \%$ of body weight daily can be considered as the optimal feeding rate for red tilapia fingerlings and It should be noted that optimal feeding rate is essential not only because of promoting best growth and minimizing Feed Conversion Rate (FCR), but also for economic and environmental aspects, preventing water quality degradation [44]. In addition to, the optimum feeding rate is helpful to minimize the feed loss, reduce water pollution and decrease 


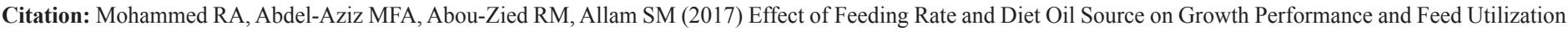
of Rabbitfish (Siganus rivulatus) Fry. J Fish Aqua Dev: JFAD-123.

cost of aquaculture production [45].

The survival rate in this study was not significantly affected by the different feeding rate, these are in agreement with (Shamoushaki et al., 2012) [40] and Deyab and Hussein, (2015) [43]. In general, the optimum feeding rate differs according to fish species, size, temperature, the availability of natural food and rearing system $[12,46]$. And the small fish would require higher feeding rates than large fish under similar culture conditions [11]. Hepatosomatic Index (HSI) was not significantly by feeding rate, this result was supported by Du et al. (2006) [45] who found that, the feeding rate did not affect significantly on HSI of grass carp juvenile.

\section{Diets Composition of Fatty Acids}

As shown in (Table 2) the diet (A, which contained fish oil as main source of fat) had a high level of saturated fatty acid SFA $(21.30 \%)$ of fatty acids and $\sum \omega-3(39.31 \%)$ of fatty acids compared with diet (B) which contained on linseed oil as main source of fat. Monounsaturated fatty acid MUFA, Arashidonic acid C20:4 $\omega 6$ and Eicosapentaenoic acid C20:5 $\omega-3$ was $24.12 \%, 3.97 \%$ and $10.79 \%$ respectively of fatty acids with diet (A) while these values were $23.65 \%, 4.08 \%$ and not detected respectively with diet (B). Diet (A) had the higher level of Eicosadienoic acid C20:2 $\omega-6$, Eicosatrienoic acid C20:3 $\omega-3$, Docosadienoic acid C22:2 than diet (B) as well as the $\operatorname{diet}(\mathrm{A})$ had the highest of Docosahexaenoic acid $\mathrm{C} 22: 6 \omega-3$ while did not detected with the diet (B).

$\sum \omega-3 / \sum \omega-6$ was higher with the $\operatorname{diet}(\mathrm{A})$ than the $\operatorname{diet}(\mathrm{B})$. On the contrary, Diet (B) had higher level of polyunsaturated fatty acid PUFA (61.18 \% of fatty acids) and $\sum \omega-6(43.02 \%$ of fatty acids) than the diet (A). Whereas, percentage of PUFA and $\sum \omega 6$ were $53.91 \%$ and $11.45 \%$ respectively for diet (A). Linoleic acid C18:206 was $38.63 \%$ of fatty acids with diet (B) while it was $4.30 \%$ with $\operatorname{diet}(\mathrm{A})$. Moreover, the diet (B) had the highest percentage of Linolenic acid C18:3 13 and it did not detect with diet (A).

\section{Effect of diet oil source on growth performance of rabbit- fish (Siganus rivulatus) fry regardless the feeding rate.}

The growth performance parameters shown in (Table 4) there were significantly affected by diet oil source, the fish fed on the diet (A) containing fish oil as main source of fat was the higher and the best in final length $\left(\mathrm{L}_{2}: 7.38 \mathrm{~cm}\right)$, final weight $\left(\mathrm{W}_{2}: 5.69\right.$ g), total weight gain (TG:5.51 g) average daily gain (ADG:0.048 g/day), relative growth rate (RGR: $3061.10 \%$ ) and specific growth rate (SGR/day: 3.01\%) than fish fed on the diet (B) containing linseed oil as main source of fat, which recorded final length $\left(\mathrm{L}_{2}\right.$ : $6.61 \mathrm{~cm}$ ), final weight $\left(\mathrm{W}_{2}: 4.46 \mathrm{~g}\right)$, total weight gain (TG:4.28 g) average daily gain (ADG:0.037g/day), relative growth rate (RGR: $2379.60 \%$ ) and specific growth rate (SGR/day: $2.80 \%$ ).

The statistical analysis did not appear significant differences between the $\operatorname{diet}(\mathrm{A})$ and the diet (B) in survival rate (SR), (HSI) and (VSI).
It can be said that, the $\operatorname{diet}(\mathrm{A})$ was the best in the growth parameters compared with the diet (B) or the fish oil positively affected on growth of rabbitfish fry in comparison with linseed oil. These results revealed the important role of fish oil in the fish feed. Whereas, the fish lipid contains predominantly unsaturated fatty acid, monounsaturated and polyunsaturated. Fish oil rich in $\omega-3$ fatty acid and most fish have requirement for $\omega-3$ fatty acids [47] as well as marine oils are superior in their fatty acid composition. The results were in agreement with) [48] who found that, red tilapia fed at fish oil diet had the highest ( $\left.\mathrm{W}_{2}\right),(\mathrm{TG}),(\mathrm{ADG})$ and (SGR) compared with the fish fed at linseed oil diet. Moreover, Izquierdo et al. (2003) [49] and Montero et al. (2008) [50] reported that, total FO substitution by vegetable oils diets in sea bass and gilthead sea bream reduced fish growth. Unlike, Masiha et al. (2013) [51] suggested that, canola and flaxseed oils can be used to replace fish oil without adverse effects on growth performance of rainbow trout fingerlings. Piedecausa et al. (2007) [15] showed that, the replacement of fish oil with soybean or linseed oil in sea bream diets does not effect on fish growth.

The analysis was showed in (Table 2) which cleared the diets composition of fatty acid, demonstrated that, the $\operatorname{diet}(\mathrm{A})$ had the high levels of SFA and $\sum \omega-3$. Moreover, the diet (A) had higher levels of MUFA than diet (B). In addition to, Eicosapentaenoic acid and Docosahexaenoic acid did not detect with diet (B). Also the $\omega-3 / \omega-6$ was the higher with the $\operatorname{diet}(\mathrm{A})$ than the $\operatorname{diet}(\mathrm{B})$. Hence, replacing fish oil in aquaculture diets presents difficulties because most vegetable oils are relatively poor sources of $\omega-3$ and longer chain $\omega-3$ highly unsaturated fatty acids fatty acids according to (NRC, 1993) [21]. As well as, Fish oil (FO) is highly digestible, which leads to increased growth, FO is also considered to increase feed appeal (FAO, 1986) [51]. This reasons resulted in the fish fed at the $\operatorname{diet}(\mathrm{A})$ was superior to fish fed at the $\operatorname{diet}(\mathrm{B})$ in the growth parameters.

With regard to Survival Rate (SR\%) it's not significantly differ between treatments, this result was similar to El-Tawil et al. (2014) [47] said that, the replacement dietary fish oil with different plant oils did not effect on survival rate of Nil tilapia and also Arslan et al., (2008) [52] found the same with juvenile surubim, there were insignificant differences in survival rate when fish oil replaced by linseed or olive oils in fish diets. In the same trend El-Tawil and Amer (2010) [53] had found with red tilapia. They suggested that, the replacement of fish oil with linseed oil in diets did not cause any negative effect on growth performance or survival rate. Lim et al. (2008) [54] indicated that, there was no significant difference in survival rate of Nile tilapia fed on fish oil or vegetable oils in diet.

The results cleared also there are not significant between the treatments in (HSI, \%) and (VSI, \%). This agrees with Babalola and Apata (2012) [55] who reported that, the HSI was not influenced by the different types dietary lipid. Tidwell et al. (2007) [56] also reported that, the HSI and VSI showed no significant 


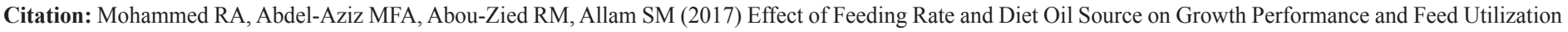
of Rabbitfish (Siganus rivulatus) Fry. J Fish Aqua Dev: JFAD-123.

differences among dietary groups $(\mathrm{P}>0.05)$ of Siganus canaliculatus. Xu et al. (2011) [57] and Aminikhoei et al. (2014) [58] found that, hepatosomatic index (HSI) and Viscerasomatic Index (VSI) were not influenced by dietary lipid sources. Moreover, Peng et al. (2008) [59] said that, did not note the differences in the HSI value of black sea bream fed FO or SBO diet.

\section{Effect of interaction between feeding rate and diet oil source of growth performance of rabbitfish (Siganus rivulatus) fry}

As shown in (Table 4) the statistical analysis revealed significantly differences between the treatments in $\left(\mathrm{L}_{2}\right),\left(\mathrm{W}_{2}\right),(\mathrm{TG})$, (ADG), (RGR), and (SGR/day, \%). The fish fed at the diet (A) with $9 \%$ feeding rate (A3) was obtained the highest $\left(\mathrm{W}_{2}\right)$, (TG), (RGR), and (SGR/day, \%) in all the treatments. The $\mathrm{W}_{2}$ did not significantly differ with the fish fed at $\operatorname{diet}(\mathrm{A})$ with $5 \%$ feeding rate (A1), 7\% feeding rate (A2) and fish fed at the diet (B) with 7 (B2), 9\% feeding rate (B3). While the fish fed at the diet (B) with $5 \%$ feeding rate (B1) obtained the lowest $\mathrm{W}_{2}$ in all the treatments. The highest TG, ADG and RGR were obtained by (A3) followed by (A2) and these parameters did not differ between (A1) and (B2), while both (B3) and (B1) had the lowest TG, ADG and RGR between the treatments. The highest SGR was recorded by (A3) and it did not differ between (A2), (B2) and (A1). While, the lowest SGR was recorded by (B3) followed by (B1). The highest $\mathrm{L}_{2}$ was recorded with (A3) and it did not differ between (A1), (A2), (B1), (B2) and (B3).

The survival rate (SR) did not significantly differ between the treatments and was not affected by feeding rate or diet oil source. This agree with $[42,47,52,60]$. The highest HSI value was obtained with (B3), HSI value did not differ between (A1), (A3), (B1) and (B2) also the lowest HSI value was obtained with (A2). VSI was higher with (A2), (A3), (B2), and (B3) than (A1) and (B1).

The results cleared that, the feeding rates with the diet (A) obtained better growth rate than the $\operatorname{diet}(\mathrm{B})$ and the relative growth of rabbitfish fry increased with increasing feeding rate from 5 to 9 $\%$ of fish body weight with the diet (A). Whereas, the $9 \%$ feeding rate with diet $\mathrm{A}$ (A3) was better in growth rate than $7 \%$ and $5 \%$ feeding rate with diet A (A2, A1). While the relative growth of rabbitfish fry decreased with increasing feeding rate from 5 to $9 \%$ of fish body weight with the diet (B) whereas, the $7 \%$ feeding rate with diet B (B2) had higher values in the most of growth parameters than (B3 and $\mathrm{B} 1)$.

These results confirmed that, fish fed at the diet (A) was better in the growth rate than the fish fed at the diet (B). This may be due to FO is highly digestible when fed to fish provided they have not oxidized, well-balanced essential fatty acids and the high level of $\omega-3$ Highly Unsaturated Fatty Acids (HUFA), which are known to be essential for the optimal growth and health of farmed fish as mentioned earlier. As well as, total FO substitution by vegetable oils in diets reduced fish growth [46-49,61].
From these results it can be observed that, the fish fed at the diet (A) their growth rate increased with increasing of the feeding rate from $5 \%$ to $9 \%$ of fish body weight, this agree with Zonneveled and Fadholi (1991) [62] who found that, the relation between growth and feeding rate is linear. Singh et al. (2003) [37] found that, percentage weight gain increased with the increase in feeding rates from 3 to $9 \%$ body weight per day and feeding rate of $9 \%$ body weight per day was observed to be better for Metynnis schreitmulleri fry fed a $35 \%$ protein diet. In the same trend the results get on with this may be due to FO is also considered to increase feed appeal $[13,38,40,41]$. This encourages farmed fish and crustaceans to locate feed and increases consumption, thereby reducing wastage [51].

On the other hand, $5 \%$ feeding rate with both the $\operatorname{diet}(\mathrm{A})$ and (B) is not sufficient for the rabbitfish fry growth, this get on with Shamoushaki et al. (2012) [39] who reported that, underfeeding is undesirable and negatively effect on growth rate. This disagree with Deyab and Hussein (2015) [42] who found that, feeding rate of $5 \%$ of body weight daily can be considered as the optimal feeding rate for red tilapia fingerlings and [63] indicated that, African catfish could be fed 5\% body weight twice a day with maximum growth and profit.

The fish fed at the diet (B) with 7\% feeding rate was better in growth performance than 5 and $9 \%$ feeding rate. This agree with studies conducted on other fish species have shown that feed consumption and growth generally

increased with feeding level up to a given limit reported that $[39,64,65]$, overfeeding above $7 \%$ feeding rate causes relatively degradation of water quality and consequently, the fish growth reduces and cost increases and they found the highest occurred in the $7.5 \% \mathrm{BW} \mathrm{d}^{-1}$ (Table 5) Effect of feeding rate and the diet oil source on feed utilization efficiency of rabbitfish (Siganus rivulatus) fry of Cyprinus carpio. A similar result was also found in sea bass (Russell et al., 1996) [66] and Rachycentron canadum (Sun et al., 2006) [67]. The best growth found at the 7.5\% and 7\% $\mathrm{BW} \mathrm{d}{ }^{-1}$.

\section{Feed Utilization Efficiency}

\section{Effect of feeding rate on feed utilization efficiency of rabbitfish (Siganus rivulatus) fry regardless the diet oil source}

Effect of feeding rate on feed utilization parameters are showed in (Table 5) the feed utilization parameters were significantly affected by the feeding rates. The highest feed intake (FI, g/ Fish) achieved by the fish fed at $9 \%$ feeding rate followed by the fish fed at $7 \%$ while the lowest (FI, g/Fish) was achieved by the fish fed at 5\%. The best (FCR) was recorded by the fish fed at 5\% feeding rate followed by $7 \%$ and the worst (FCR) was obtained by $9 \%$ feeding rate, in the same trend was (FCE). 
Citation: Mohammed RA, Abdel-Aziz MFA, Abou-Zied RM, Allam SM (2017) Effect of Feeding Rate and Diet Oil Source on Growth Performance and Feed Utilization of Rabbitfish (Siganus rivulatus) Fry. J Fish Aqua Dev: JFAD-123.

\begin{tabular}{|c|c|c|c|c|c|c|c|c|}
\hline $\begin{array}{c}\text { Items \& } \\
\text { Treatments }\end{array}$ & FI, g/ fish & FCR & FCE, \% & PER & PPV, \% & EER, g/Kcal & EPV, \% & LR, \% \\
\hline \multicolumn{9}{|c|}{ Effect of feeding rate regardless the diet oil source } \\
\hline Feeding rate $5 \%$ & $12.36^{\mathrm{c}}$ & $2.98^{\mathrm{c}}$ & $33.57^{\mathrm{a}}$ & $0.92^{\mathrm{a}}$ & $37.01^{\mathrm{a}}$ & $0.065^{\mathrm{a}}$ & $42.71^{\mathrm{a}}$ & $109.52^{\mathrm{a}}$ \\
\hline Feeding rate $7 \%$ & $20.64^{b}$ & $4.05^{\mathrm{b}}$ & $24.76^{\mathrm{b}}$ & $0.67^{\mathrm{b}}$ & $27.60^{\mathrm{b}}$ & $0.048^{\mathrm{b}}$ & $33.33^{\mathrm{b}}$ & $87.37^{\mathrm{b}}$ \\
\hline Feeding rate $9 \%$ & $28.10^{\mathrm{a}}$ & $5.17^{\mathrm{a}}$ & $19.30^{\mathrm{c}}$ & $0.52^{\mathrm{c}}$ & $20.57^{\mathrm{c}}$ & $0.037^{\mathrm{c}}$ & $26.98^{\mathrm{c}}$ & $73.10^{\mathrm{c}}$ \\
\hline SED $^{*}$ & 2.770 & 0.170 & 0.250 & 0.008 & 0.690 & 0.0007 & 1.190 & 5.560 \\
\hline \multicolumn{9}{|c|}{ Effect of diet oil source regardless the feeding rate } \\
\hline Diet (A) Fish oil & 22.88 & 4.04 & 25.98 & 0.71 & 28.91 & 0.051 & 33.12 & 84.32 \\
\hline Diet (B) Linseed oil & 17.85 & 4.07 & 25.73 & 0.70 & 27.86 & 0.050 & 35.50 & 95.67 \\
\hline $\mathrm{SED}^{*}$ & 4.300 & 0.580 & 3.700 & 0.103 & 4.280 & 0.007 & 4.110 & 9.770 \\
\hline \multicolumn{9}{|c|}{ Effect of interaction between feeding rate and diet oil source } \\
\hline Diet (A) \& Feeding rate $5 \%(\mathrm{~A} 1)$ & $14.22^{\mathrm{bc}}$ & $2.94^{\mathrm{c}}$ & $33.76^{\mathrm{a}}$ & $0.93^{\mathrm{a}}$ & $38.37^{\mathrm{a}}$ & $0.066^{\mathrm{a}}$ & $41.21^{\mathrm{b}}$ & $101.55^{\mathrm{b}}$ \\
\hline Diet (A) \& Feeding rate $7 \%(\mathrm{~A} 2)$ & $21.78^{\mathrm{b}}$ & $4.02^{\mathrm{b}}$ & $24.82^{\mathrm{b}}$ & $0.68^{\mathrm{b}}$ & $28.10^{\mathrm{c}}$ & $0.048^{\mathrm{b}}$ & $31.31^{\mathrm{d}}$ & $78.67^{\mathrm{d}}$ \\
\hline Diet (A) \& Feeding rate $9 \%(\mathrm{~A} 3)$ & $32.65^{\mathrm{a}}$ & $5.15^{\mathrm{a}}$ & $19.35^{\mathrm{c}}$ & $0.53^{\mathrm{c}}$ & $20.30^{\mathrm{f}}$ & $0.038^{c}$ & $26.86^{\mathrm{f}}$ & $72.75^{\mathrm{f}}$ \\
\hline Diet (B) \& Feeding rate $5 \%(\mathrm{~B} 1)$ & $10.50^{\mathrm{c}}$ & $3.00^{\mathrm{c}}$ & $33.23^{\mathrm{a}}$ & $0.91^{\mathrm{a}}$ & $35.66^{\mathrm{b}}$ & $0.065^{\mathrm{a}}$ & $44.22^{\mathrm{a}}$ & $117.50^{\mathrm{a}}$ \\
\hline Diet (B) \& Feeding rate $7 \%(\mathrm{~B} 2)$ & $19.50^{\mathrm{ab}}$ & $4.04^{\mathrm{b}}$ & $24.71^{\mathrm{b}}$ & $0.67^{\mathrm{b}}$ & $27.09^{\mathrm{d}}$ & $0.048^{\mathrm{b}}$ & $35.35^{\mathrm{c}}$ & $96.07^{\mathrm{c}}$ \\
\hline Diet (B) \& Feeding rate $9 \%(B 3)$ & $23.56^{\mathrm{b}}$ & $5.19^{\mathrm{a}}$ & $19.25^{\mathrm{c}}$ & $0.52^{\mathrm{c}}$ & $20.85^{\mathrm{e}}$ & $0.037^{\mathrm{c}}$ & $27.11^{\mathrm{e}}$ & $73.44^{\mathrm{e}}$ \\
\hline SED $^{*}$ & 2.490 & 0.290 & 0.370 & 0.010 & 0.014 & 0.001 & 0.014 & 0.054 \\
\hline
\end{tabular}

Table 5: Effect of feeding rate and the diet oil source on feed utilization efficiency of rabbitfish (Siganus rivulatus) fry

The highest value of PER, PPV, EER, EPV, and LR was achieved with the fish fed $5 \%$ feeding rate followed by $7 \%$ but the lowest value of these parameters were recorded by $9 \%$ feeding rate.

The results are shown in (Table 5) Fish fed at 5\% feeding rate was the best in all of the feed utilization parameters followed by $7 \%$ feeding rate while the fish fed at $9 \%$ feeding rate was the worst in all the feed utilization parameters. This was in agreement with, Deyab and Hussein (2015) [42] who found that, the FCR values increased with increasing feeding rates. Ashley-dejo et al. (2014) [63] reported that, the highest PER and low FCR in treatments fed $3 \%$ body weight followed by 4 and $5 \%$ body weight respectively. Also, feed efficiency decreased linearly with the increasing feeding rate from 1 to $3 \% \mathrm{BW} /$ day (Du et al., 2006) [44]. As well as, over-feeding of fish will cause the overload of stomach and intestine, and decrease the efficiency of digestion and absorption (Jobling, 1986) [69], and thus reduces feed efficiency (Hung and Lutes, 1987) [70].

\section{Effect of diet oil source on feed utilization efficiency of rabbitfish (Siganus rivulatus) fry regardless the feeding rate}

As shown in (Table 5) The statistical analysis do not show any significant differences between the fish fed at the diet (A) and diet (B) in all the feed utilization parameters. This agree with Aminikhoei et al. (2014) [58] reported that, four is nitrogenous and isolipidic diets were formulated with either Fish Oil (FO), Soybean Oil (SBO), Linseed Oil (LO) or a mixture of SBO and LO $(\mathrm{SBO}+\mathrm{LO})$, the results showed that, the feed efficiency and protein efficiency ratios of black sea bream were not affected by dietary lipid sources ( $\mathrm{p}>0.05)$.

El-Tawil and Amer (2010) [53] observed no significant differences $(\mathrm{P}>0.05)$ between PER values of red tilapia fed on fish oil or linseed oil diets. Tidwell et al. (2007) [56] studied that, the effects of feeding diets supplemented with oils of varying sources of juvenile Largemouth Bass and they found the feed utilization efficiency (i.e., FCR) were not significantly different.

Moreover, Bahurmiz and $\mathrm{Ng}$ (2007) [71] stated that, the feed utilization efficiency of red hybrid tilapia fed the FO or the three palm oil-based diets were not significantly different $(\mathrm{P}>0.05)$. Feed conversion ratio and protein efficiency ratio did not differ statistically among dietary groups. Other study evaluated the suitability of canola and flaxseed oils as source of supplemental dietary lipid for fingerlings of rainbow trout, this study reported insignificant differences in FCR between the treatments (Masiha et al. 2013) [50]. 


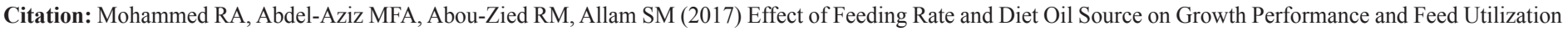
of Rabbitfish (Siganus rivulatus) Fry. J Fish Aqua Dev: JFAD-123.

On the other hand, these results disagree with (Ali et al., 2000 [72], Bablola and Apata, 2012 [55], Thiaw, 2013 [73] and El-Tawil et al., 2014) [47] all these references reported that, the feed efficiency is affected by the dietary oil source.

\section{Effect of interaction between feeding rate and diet oil source on feed utilization efficiency of rabbitfish (Siganus rivulatus) fry}

The interaction between feeding rate and diet oil source on feed utilization of rabbitfish fry are showed in (Table 5) the results appeared significant differences in all the feed utilization parameters between the treatments. The highest values of Feed Intake (FI) were recorded with the fish fed at the $\operatorname{diet}(\mathrm{A})$ compared with the diet (B) this may be return to the positive effect of fish oil on the feed consumption as lately mention. And the lowest (FI) was achieved with (B1) and (A1) followed by (B2) and (A2) while the highest values of (FI) recorded by (A3) and (B3) this are naturally, whereas the feed intake increases with increasing the feeding rate.

The best FCR value was achieved with (A1) and (B1) followed by (A2) and (B2) while the worst of FCR recorded by (A3) and (B3) in the same trended was FCE, PER and EER. The highest level of PPV was recorded by (A1) followed by (B1), (A2), (B2), (B3) and (A3) respectively. The highest value of EPV and LR was recorded by (B1) followed by (A1), (B2), (A2), (B3) and (A3) respectively. From these results it can be observed the feed utilization parameters inversely related with increasing of the feeding rate, this are in agreement with El-Dakar et al. (2010) [74] who reported that, increasing feed level resulted in an increase of energy lost in the feces as a proportion of the energy intake. It may be decrease the efficiency of digestion and absorption. Therefore, not all feed intake converted to growth by fish. Study of El- Dakar (1999) [75] showed that FCR, PER and PPV improved by decreasing feeding level. In the same trend these results get on with EL-Sayed et al. (1993) [76], El- Meligi (2003) [77], Yufera et al. (1995) [78], ElSayed (2002) [79], Du et al. (2006) [44], Ashley-dejo et al. (2014) [63] and Deyab and Hussein (2015) [42].

\section{Whole Body Chemical Composition and Energy Content}

\section{Effect of feeding rate on whole body chemical composi- tion and energy content of rabbitfish (Siganus rivulatus) fry regardless the diet oil source}

Whole body chemical composition and energy content of whole body rabbitfish fry (Siganus rivulatus) at the beginning and the end of the experimental period are shown in (Table 6) there were significant differences between the treatments at the end of the experimental period in Dry Matter (DM), Ether Extract (EE) and Gross Energy (GE). While, there were insignificant differences in crude protein $\mathrm{CP}$ and ash between the treatments.

(Table 6) cleared that, DM, EE and GE increased with increasing of feeding rate whereas the highest value of DM, EE and GE was achieved by the fish fed at $9 \%$ feeding rate followed by $7 \%$ feeding rate and $5 \%$ was the lowest in this items. This completely agree with $\mathrm{Du}$ et al. (2006) [44] who found that, the body content of $\mathrm{CP}$ and ash was not significantly differed by feeding rates and DM, EE increased with increasing of the feeding rate. Moreover, Spadefish fed at higher feeding rates accumulated significantly more lipid within the body and had an associated decrease in moisture, protein, and ash content (Trushenski et al., 2012) [38]. However, Ghousia and Shantha (2001) [80] who found that protein increased with increasing feeding rate, while the fat increased with decreasing feeding rate.

\begin{tabular}{|c|c|c|c|c|c|c|}
\hline Items \& Treatments & $\begin{array}{c}\text { Moisture } \\
\text { (M, \%) }\end{array}$ & $\begin{array}{c}\text { Dry matter } \\
\text { (DM, \%) }\end{array}$ & $\begin{array}{c}\text { Crude protein } \\
\text { (CP, \%) }\end{array}$ & $\begin{array}{c}\text { Ether extract } \\
(\mathrm{EE}, \%)\end{array}$ & $\begin{array}{c}\text { Ash, } \\
\%\end{array}$ & $\begin{array}{l}\text { Gross energy } \\
(\mathrm{GE}, \mathrm{Kcal} / \mathrm{g})\end{array}$ \\
\hline Start & 80.70 & 19.30 & 50.17 & 9.75 & 34.57 & 3.68 \\
\hline \multicolumn{7}{|c|}{ Effect of feeding rate regardless the diet oil source } \\
\hline Feeding rate $5 \%$ & $63.86^{\mathrm{a}}$ & $36.14^{\mathrm{b}}$ & 40.61 & $43.50^{\mathrm{b}}$ & 10.57 & $6.32^{b}$ \\
\hline Feeding rate $7 \%$ & $61.75^{\mathrm{ab}}$ & $38.25^{\mathrm{ab}}$ & 40.97 & $47.34^{\mathrm{ab}}$ & 9.63 & $6.75^{\mathrm{ab}}$ \\
\hline Feeding rate $9 \%$ & $60.51^{\mathrm{b}}$ & $39.49^{\mathrm{a}}$ & 39.18 & $51.01^{\mathrm{a}}$ & 9.22 & $7.00^{\mathrm{a}}$ \\
\hline SED $^{*}$ & 1.16 & 1.16 & 0.87 & 2.84 & 1.13 & 0.24 \\
\hline \multicolumn{7}{|c|}{ Effect of diet oil source regardless the feeding rate } \\
\hline Diet (A) Fish oil & $63.25^{\mathrm{a}}$ & $36.75^{\mathrm{b}}$ & 40.60 & $44.68^{\mathrm{b}}$ & $10.76^{\mathrm{a}}$ & 6.47 \\
\hline Diet (B) Linseed oil & $60.84^{\mathrm{b}}$ & $39.16^{\mathrm{a}}$ & 39.90 & $49.89^{\mathrm{a}}$ & $8.85^{\mathrm{b}}$ & 6.90 \\
\hline SED $^{*}$ & 0.990 & 0.990 & 0.806 & 2.435 & 0.734 & 0.217 \\
\hline \multicolumn{7}{|c|}{ Effect of interaction between feeding rate and diet oil source } \\
\hline Diet (A) \& Feeding rate $5 \%(\mathrm{~A} 1)$ & $65.51^{\mathrm{a}}$ & $34.49^{\mathrm{f}}$ & $41.64^{\mathrm{a}}$ & $40.23^{\mathrm{d}}$ & $12.17^{\mathrm{a}}$ & $6.11^{\mathrm{c}}$ \\
\hline Diet (A) \& Feeding rate 7\% (A2) & $63.57^{\mathrm{b}}$ & $36.43^{\mathrm{e}}$ & $41.65^{\mathrm{a}}$ & $42.71^{\mathrm{cd}}$ & $11.09^{\mathrm{ab}}$ & $6.35^{\mathrm{c}}$ \\
\hline Diet (A) \& Feeding rate $9 \%(\mathrm{~A} 3)$ & $60.67^{\mathrm{d}}$ & $39.33^{\mathrm{c}}$ & $38.53^{\mathrm{b}}$ & $51.10^{\mathrm{ab}}$ & $9.02^{\mathrm{bc}}$ & $6.97^{\mathrm{ab}}$ \\
\hline
\end{tabular}


Citation: Mohammed RA, Abdel-Aziz MFA, Abou-Zied RM, Allam SM (2017) Effect of Feeding Rate and Diet Oil Source on Growth Performance and Feed Utilization of Rabbitfish (Siganus rivulatus) Fry. J Fish Aqua Dev: JFAD-123.

\begin{tabular}{|c|c|c|c|c|c|c|}
\hline Diet (B) \& Feeding rate 5\% (B1) & $62.22^{\mathrm{c}}$ & $37.78^{\mathrm{d}}$ & $39.57^{\mathrm{ab}}$ & $46.78^{\mathrm{bc}}$ & $8.98^{\mathrm{bc}}$ & $6.54^{\mathrm{bc}}$ \\
\hline Diet (B) \& Feeding rate 7\% (B2) & $59.94^{\mathrm{f}}$ & $40.06^{\mathrm{a}}$ & $40.30^{\mathrm{ab}}$ & $51.98^{\mathrm{a}}$ & $8.16^{\mathrm{c}}$ & $7.15^{\mathrm{a}}$ \\
\hline Diet (B) \& Feeding rate 9\% (B3) & $60.36^{\mathrm{e}}$ & $39.64^{\mathrm{b}}$ & $39.83^{\mathrm{ab}}$ & $50.93^{\mathrm{ab}}$ & $9.41^{\mathrm{bc}}$ & $7.03^{\mathrm{a}}$ \\
\hline SED $^{*}$ & 0.017 & 0.017 & 1.000 & 1.730 & 0.850 & 0.180 \\
\hline
\end{tabular}

(a, b, c, d, e and f) Average in the same column having different superscripts significantly different at $(\mathrm{P} \leq 0.05)$.

*SED is the Standard Error of Difference.

Table 6: Effect of feeding rate and the diet oil source on whole body chemical composition and energy content of rabbitfish (Siganus rivulatus) fry.

\section{Effect of diet oil source on whole body chemical composi- tion and energy content of rabbitfish (Siganus rivulatus) fry regardless the feeding rate}

Whole body chemical composition and energy content of rabbitfish fry (Siganus rivulatus) at the beginning and the end of the experimental period are shown in (Table 6) there were significant differences in the DM, EE and ash content of whole body rabbitfish fry at the end of the experimental period between the fish fed at the diet (A) and (B). While, the CP and GE were not significantly differences between the fish fed at the $\operatorname{diet}(\mathrm{A})$ and (B). The DM and EE were higher with $\operatorname{diet}(\mathrm{B})$ than $\operatorname{diet}(\mathrm{A})$. This result partial agrees with Tidwell et al. (2007) [56] who found that, the EE increased in Largemouth bass whole body which fed on linseed oil diet than fish fed at diet contained on fish oil. Unlike, [58] reported that, dietary lipid source did not effect on lipid of Black Sea bream muscle.

\section{Effect of interaction between feeding rate and diet oil source on whole body chemical composition and energy content of rabbitfish (Siganus rivulatus) fry}

The interaction between feeding rate and diet oil source on whole body chemical composition and energy content of rabbitfish fry (Siganus rivulatus) at the beginning and the end of the experimental period are shown in (Table 6) there were significant differences in the DM, CP, EE, ash content and GE of whole body rabbitfish fry at the end of the experimental period between the fish fed at the diet (A) and (B) with different feeding rate.

The (B2) had the highest DM followed by (B3), (A3), (B1), (A2) and (A1) respectively, the highest $\mathrm{CP}$ was achieved by (A1) and (A2), the (B1), (B2), (B3) did not differ in CP and the lowest $\mathrm{CP}$ was achieved by (A3). The highest $\mathrm{EE}$ was achieved with (B2) followed by (A3), (B3), (B1), (A2) and (A1) respectively. The highest ash content was obtained by (A1) followed by (A2) and insignificant between (B3), (A3) and (B1) while the lowest ash was with (B2). The highest GE was achieved by (B2) and (B3) followed by (A3), (B1) and the lowest GE was with (A2) and (A1).

In general, the DM, EE and GE for fish fed at diet (A) increased with increasing of the feeding rate, the (B2) had higher $\mathrm{DM}, \mathrm{EE}$ and GE than (B3) and (B1). It can be observed that, the fish had high growth were the highest in DM, EE and GE. This may be due to an increase of feeding rate accumulated significantly more lipid according to (Trushenski et al. 2012) [38].

\section{Conclusion}

The growth parameters values increased with increasing the feeding rate but the growth performance and survival rate were not significantly affected by the different feeding rates regardless the diet oil source. it can be said the lowest of feeding rate of 5\% was the better than $7 \%$ and $9 \%$ feeding rate in terms of reducing of feed offered per fish and this lead to reducing of the cost production. Also, it can be said that the diet (A) which contained on fish oil as main source of fat was the best in the growth parameters compared with the diet (B) or the fish oil positively affected on growth of rabbitfish fry in comparison with linseed oil regardless the feeding rates.

It can be concluded that, the interaction between the feeding rates and the dietary oil source cleared that the $9 \%$ and $7 \%$ feeding rate with $\operatorname{diet}(\mathrm{A})$ achieved the highest growth compared with the other treatments in both $\operatorname{diet}(\mathrm{A})$ and $(\mathrm{B})$, the $5 \%$ feeding rate with $\operatorname{diet}(\mathrm{A})$ equaled with the $7 \%$ feeding rate with $\operatorname{diet}(\mathrm{B})$ in growth performance.

\section{References}

1. Woodland DJ (1990) Revision of the fish family Siganidae with descriptions of two new species and comments on distribution and biology. Indo-Pacific Fishes, No. 19 Bernice Pauahi Bishop Museum, Honolulu, Hawaii 136.

2. Woodland DJ (1983) Zoogeography of the Siganidae (Pisces) and interpretation of distribution and richness pattern. Bulletin of Mar Sci 33: 713-717.

3. Duray MN (1990) Biology and culture of siganids. Aquaculture Department, Southeast Asian Fisheries Development Center, Tigbauan, Iloilo, Philippines.

4. Saoud P, Hanawi JG, Lebbos N (2007a) Effects of stocking density on the survival, growth, size variation and condition index of juvenile rabbitfish (Siganus rivulatus). Aquacult Int 10: 9129-9127.

5. Lam TJ (1974) Siganids: their biology and mariculture potential. Aquacult 3: 325-354.

6. Hara S, Duray MN, Parazo M, Taki Y (1986) Year-round spawning and seed production of the Rabbitfish (Siganus guttatus). Aquacult 59: 259-272. 
Citation: Mohammed RA, Abdel-Aziz MFA, Abou-Zied RM, Allam SM (2017) Effect of Feeding Rate and Diet Oil Source on Growth Performance and Feed Utilization of Rabbitfish (Siganus rivulatus) Fry. J Fish Aqua Dev: JFAD-123.

7. Stephanou D, Georgiou G (2000) Recent Experiences on the Culture of Rabbitfish (Siganus rivulatus) in Cyprus. CIHEAM-IAMZ, Zaragoza 95-301.

8. Türker A, Yildirim O (2011) The effect of feeding frequency on growth performance and body composition in juvenile rainbow trout (Oncorhynchus mykiss) reared in cold seawater. Afr J Biotechnol 10: 94799484.

9. FAO (2012) The State of World Fisheries and Aquaculture 2012. Published by Food and Agriculture Organization, Rome: 1-230.

10. Ng WK, Lu KS, Hashim R, Ali A (2000) Effects of feeding rate on growth, feed utilization and body composition of tropical bagrid catfish. Aquacult Int 8: 19-29.

11. Cho SH, Lim YS, Lee JH, Park S (2003) Effect of feeding rate and feeding frequency on survival, growth, and body composition of ayu post-larvae (Plecoglossus altivelis). J World Aquacult Soc 34: 85-91.

12. Mihelakakis A, Tsolkas C, Yoshimatsu T (2002) Optimization of feeding rate for hatchery-produced juvenile gilthead sea bream (Sparus aurata). J World Aquacult Soc 33: 169-175.

13. Fountoulaki E, Vasilaki A, Hurtado R, Grigorakis K, Karacostas I, et al. (2009) Fish oil substitution by vegetable oils in commercial diets for gilthead sea bream (Sparus aurata L.); effects on growth performance, flesh quality and fillet fatty acid profile recovery of fatty acid profiles by a fish oil finishing diet under fluctuating water temperatures. Aquacult 289: 317-326.

14. Francis DS, Turchini GM, Jones PL, De Silva SS (2006) Effect of dietary oil on the growth and muscle fatty acid composition of Murray cod (Maccullochella peelii). Aquacult 253: 547-556.

15. Piedecausa MA, Mazón MJ, García García B, Hernández MD (2007) Effects of total replacement of fish oil by vegetable oils in the diets of sharp snout sea bream (Diplodus puntazzo). Aquacult 263: 211-219.

16. Lim PK, Boey PL, Ng WK (2001) Dietary palm oil level affects growth performance, protein retention and tissue vitamin $\mathrm{E}$ concentration of African catfish (Clarias gariepinus). Aquacult 202: 101-112.

17. Caballero MJ, Obach A, Rosenlund G, Montero D, Gisvold M, et al. (2002) Impact of different dietary lipid sources on growth, lipid digestibility, tissue fatty acid composition and histology of rainbow trout (Oncorhynchus mykiss). Aquacult 214: 253-271.

18. Owen JM, Adron JW, Middleton C, Cowey CB (1975) Elongation and Desaturation of Dietary Fatty Acids in Turbot (Scophthalmus maximus L.) and Rainbow Trout (Salmo gairdnerii Rich). Lipids 10: 528-531.

19. AOAC (1984) Official Methods of Analysis. Williams S (Ed) Association of Official Analytic Chemists, Inc. Arlington, Virg. USA.

20. NRC (1993) National Research Council, Nutrient requirements of fish. National Academy Press, Washington DC USA.

21. Mullin JB, Riley JP (1955) The spectrophotometric determination of nitrate in natural waters, with particular references to see water. Analytica, chemica ACTA 12: 464-480.

22. APHA (1992) Standard Methods for the Examination of Water and Waste water. $18^{\text {th }}$ Edition. Amer. Public Health Assoc., Washington DC1268.

23. Viola S, Malady S, Rappaport U (1981) Partial and complete replacement of fish meal by soybean meal in feeds for Intensive culture of carp. Aquacult 26: 223-236.
24. Egan H, Kirk RS, Sawyer R, Pearson D (1981) Pearson's chemical analysis of foods. $8^{\text {th }}$ Edn., Churchill Livingstone: 537.

25. Jumat S, Mamot S, Suria R, Mohamad A (2006) Oil and Fat Analysis, UKM Press, Bangi, Malaysia.

26. Siew WL, Tang TS, Tan YA (1995) PORIM Test Methods Vol. 1. Bandar Baru Bangi, Kuala Lumpur, Palm Oil Research Institute of Malaysia.

27. Dauqan E, Sani HA, Abdullah A, Muhamad H, Gapor MD, et al. (2011) Vitamin $\mathrm{E}$ and beta carotene composition in four different vegetable oils. Amer J Appl Sci 8: 407-412.

28. SPSS (2007) Statistical Package for Social Science (for Windows). Release 16 Copyright $\odot$, SPSS Inc., Chicago, USA.

29. Westernhagen HM, Rosenthal H (1975) Rearing and spawning siganids (Pisces: Teleostei) in a closed sea water system. Helgol. Wiss Meeresunters 27:1-18.

30. Huguenin JE, Colt J (1989) Design and Operating Guide for Aquaculture Seawater Systems. Elsevier, Amsterdam. Dev Aquacult Fish Sci 20: 264.

31. Meade JW (1989) Aquaculture Management. New Branch. York: Van Nostrand Reinhold.

32. Davis J (1993) Survey of Aquaculture effluents permitting and standards in the South. Southern Regional Aquaculture Centre, SRAC publication USA.

33. Lawson TB (1995) Fundamentals of Aquaculture Engineering. New York: Chapman \& Hall: 355.

34. ANZECC (2000) (Australian and New Zealand Environment and Conservation Council) and ARMCANZ (Agriculture and Resource Management Council of Australia and New Zealand), Australian Guidelines for Water Quality Monitoring and Reporting. National Water Quality Management Strategy Paper No. 7, ANZECC and ARMCANZ, Canberra.

35. EPA (2003) The Environment Protection (Water Quality) Policyían overview, both the overview and a copy of the Water Quality Policy with an accompanying explanatory report are available on the EPA.

36. Saoud IP, Kreydiyyeh S, Chalfoun A, Fakih M (2007b) Influence of salinity on survival, growth, plasma osmolality and gill Na-K-ATPase activity in the rabbitfish (Siganus rivulatus). J Exp Mar Biol Ecol 348: 183-190.

37. Saoud IP, Mohanna C, Ghanawi J (2008) Effects of temperature on survival and growth of juvenile spinefoot rabbitfish (Siganus rivulatus) Aquacult Res 39: 491-497.

38. Singh RK, Vartak VR, Balange AK, Chavan JB (2003) The effect of feeding rate on the growth, food conversion protein efficiency of Silver dollar, (Metynnis schreitmulleri) fry. J Indian Fisheries Assoc 30: 105-118.

39. Trushenski J, Rombenso A, Schwarz MH, Bowzer J, Gause B, et al (2012) Feeding rate and frequency affect growth of juvenile Atlantic spadefish. North Amer J Aquacult 74: 107-112.

40. Shamoushaki MMN, Khari Z, Eslami Z (2012) Determination of optimum feeding rate for growth of Caspian carp (Cyprinus carpio Linnaeus, 1758) fingerlings. AACL Bioflux 5: 136-141.

41. Eroldogan OT, Kumlu M, Aktas M (2004) Optimum feeding rates for European sea bass (Dicentrarchus labrax L.) reared in seawater and freshwater. Aquacult 231: 501-515. 
Citation: Mohammed RA, Abdel-Aziz MFA, Abou-Zied RM, Allam SM (2017) Effect of Feeding Rate and Diet Oil Source on Growth Performance and Feed Utilization of Rabbitfish (Siganus rivulatus) Fry. J Fish Aqua Dev: JFAD-123.

42. Silva CR, Gomes LC, Brandao FR (2007) Effects of feeding rate and frequency on Tambaqui (Colossoma macropomum) growth, production and feeding costs during the first growth phase in cages. Aquacult 264: 135-139.

43. Deyab EDM, Hussein EEM (2015) Effects of Different Feeding Rates on Growth Performance and Body Composition of Red Tilapia, (Oreochromis mossambiqusex 0 . niloticus) Fingerlings. Int J Aquacult 12: 1-7.

44. Yuan YC, Yang HJ, Gong SY, Luo Z, Yuan HW, et al. (2010) Effects of feeding levels on growth performance, feed utilization, body composition and apparent digestibility coefficients of nutrients for juvenile Chinese sucker (Myxocyprinus asiaticus). Aquacult Res 41: 1030-1042.

45. Du ZY, Liu YJ, Tian LX, He JG, Cao JM, et al. (2006) The influence of feeding rate on growth, feed efficiency and body composition of juvenile grass carp (Ctenopharyngodon idella). Aquacult Int 14: 247-257.

46. Ibrahim EM (2011) Effect of different feeding rates on growth performance some biochemical traits of Common carp (Cyprinus Carpio) and its economic efficiency. J Arabian aquacult Soc 6: 1-12.

47. Pike HI (1990) The role of fish oil in feeds for farmed fish. International Association of Fish Meal Manufacturers (IAFMM).

48. El-Tawil NE, Ahmad MH, Amer TN, Seden ME (2014) Effect of Replacing Dietary Fish Oil with Different Plant Oils on growth performance of Nile tilapia (Oreochromis niloticus). Appl Sci Res 1: 183-191.

49. Izquierdo MS, Obach A, Arantzamendi L, Montero D, Robaina L (2003) Dietary lipid sources for sea bream and sea bass: growth performance, tissue composition and flesh quality. Aquacult Nutr 9: 397-407.

50. Montero D, Grasso V, Izquierdo MS, Ganga R, Real F, et al. (2008) Total substitution of fish oil by vegetable oils in gilthead sea bream (Sparus aurata) diets: Effects on hepatic Mx expression and some immune parameters. Fish \& Shellfish Immunol 24: 147-155.

51. Masiha A, Ebrahimi1 E, Soofiani NM, Kadivar M (2013) Effect of Dietary Vegetable Oils on the Growth Performance and Fatty Acid Composition of Fingerlings of Rainbow Trout (Oncorhynchus mykiss). Food Sci and Technol 1: 21-29.

52. FAO (1986) FAO Fisheries Technical Paper-142, the production of fish meal and oil. Fisheries Technical Division, Food \& Agric. Organisation, Rome: 63.

53. Arslan M, Rinchard J, Dabrowskii K, Portella MS (2008) Effects of different dietary lipid sources on the survival, growth, and fatty acid composition of south American catfish, (Pseudoplatystoma fasciatum) Surubim, Juveniles. J World Aquacult Soc 39: 51-61.

54. El-Tawil NE, Amer TN (2010) Effect of different dietary oil sources on fish performance, feed utilization and body composition of Red Tilapia (Oreochromis sp.) fry. Abbasa Int J Aquacult Spicial Issue $3^{\text {rd }}$ Sci Conf, Al Azhar Uni., Cairo 17-18 October 2010 161-177.

55. Lim C, Aksoy MY, Davis A, Klesius P (2008) Effects of varied dietary lipid sources tested in tilapia study. Global Aquacult Advocate 67-70.

56. BabalolaTO,Apata FA(2012) Effects of dietary lipid source on growth, digestibility and tissue fatty acid composition of (Heterobranchus longifilis) fingerlings. J Agric \& Rural Dev in the Tropics and Subtropics 113: 1-11.

57. Tidwell JH, Coyle S, Bright LA (2007) Effects of Different Types of Dietary Lipids on Growth and Fatty Acid Composition of Largemouth Bass. North Amer J Aquacult 69:257-264.
58. Xu S, Wang S, Zhang L, You C, Li Y (2011) Effects of replacement of dietary fish oil with soybean oil on growth performance and tissue fatty acid composition in marine herbivorous teleost (Siganus canaliculatus). Aquacult Res 43: 1276-1286.

59. Aminikhoei Z, Choi J, Lee S (2014) Impacts of different dietary lipid sources on growth performance, fatty acid composition and antioxidant enzyme activity of juvenile Black Sea bream (Acanthopagrus schlegeli). Iranian J Fisheries Sci 13: 796-809.

60. Peng S, Chen L, Qin JG, Hou J, Yu N, et al. (2008) Effects of replacement of dietary fish oil by soybean oil on growth performance and liver biochemical composition in juvenile black sea bream (Acanthopagrus schlegeli). Aquacult 276: 154-161.

61. Al Zahrani AW, Mohamed AH, Jr AES, Traifalgar RFM (2013) Effects of feeding rate and frequency on growth and feed utilization efficiency in the camouflage grouper (Epinephelus polyphekadion) fingerlings fed a commercial diet. European J Exp Biol 3: 596-601.

62. Turchini GM, Torstensen BE, Ng W (2009) Fish oil replacement in finfish nutrition. Rev Aquacult 1: 10-57.

63. Zonneveld N, Fadholi R (1991) Feed intake and growth of red tilapia at different stocking densities in ponds in Indonesia. Aquacult 99: 83-94.

64. Ashley-dejo SS, Olaoye OJ, Adelaja OA, Abdulraheem I (2014) Effects of feeding levels on growth performance feed utilization and body composition of African catfish (Clarias gariepinus, Burchell 1822). Int J Biol \& Biological Sci 3: 012-016.

65. Wang N, Hayward RS, Noltie DB (1998) Effect of feeding frequency on food consumption, growth, size variation, and feeding pattern of Agehybrid Sunfish. Aquacult 165: 261-267.

66. Bascinar NE, Cakmak Y, Cardar Aksunga N (2007) The Effect of Feeding Frequency on Growth Performance and Feed Conversion Rate of Black Sea trout (Salmo trutta, 1811). Turk J Fisheries \& Aquat Sci 7: 13-17.

67. Russell NR, Fish JD, Wootton RJ (1996) Feeding and growth of juvenile sea bass: the effect of ration and temperature on growth rate and efficiency. J Fish Biol 49: 206-220.

68. Sun L, Chen H, Huang L, Wang Z (2006) Growth, faecal production, nitrogenous excretion and energy budget of juvenile cobia (Rachycentron canadum) relative to feed type and ration level. Aquacult 259: 211-221.

69. Jobling M (1986) Gastrointestinal overload-a problem with formulated feed? Aquacult 51: 257-263.

70. Hung SSO, Lutes PB (1987) Optimum feeding rate of hatchery-product juvenile white sturgeon (Acipenser transmontanus) at $20^{\circ} \mathrm{C}$. Aquacult 65: $307-317$.

71. Bahurmiz OM, Ng W-K (2007) Effects of dietary palm oil source on growth, tissue fatty acid composition and nutrient digestibility of red hybrid tilapia (Oreochromis sp.) raised from stocking to marketable size. Aquacult 262: 382-392.

72. Ali A, Al-Ogaily SM, Al-Asgah NA, Ali S (2000) Effect of dietary lipid source on the growth performance and body composition of (Oreochromis niloticus). Pakistan Vet J 20: 57-63.1

73. Thiaw OT (2013) Effects of Different Types of Oils on Growth Performance, Survival and Carcass Composition of Nile Tilapia (Oreochromis niloticus). J Biol Life Sci 4: 1-12. 
Citation: Mohammed RA, Abdel-Aziz MFA, Abou-Zied RM, Allam SM (2017) Effect of Feeding Rate and Diet Oil Source on Growth Performance and Feed Utilization of Rabbitfish (Siganus rivulatus) Fry. J Fish Aqua Dev: JFAD-123.

74. El-Dakar A, Hassanen G, ShalabyShymaa, Ghoniem S, Zenhom O (2010) Survival, Growth, Feed Efficiency and Carcass Composition of Rabbitfish (Siganus rivulatus) Fed Different Dietary Energy and Feeding Levels. J Mediterranean Aquacult 1: 18-27.

75. El-Dakar AY (1999) Effect of different feeding levels on performance of rabbitfish (Siganus revulatus) fingerlings. Egyptian J Aquat Biol \& Fisheries 3: 35-54.

76. El-Sayed AM, Mostafa KA, Mohammadi JS, Dohaimi AA, Kayid M (1993) Intensive culture of rabbitfish in Qatar: Effects of stocking density and feeding level on growth rates and feed utilization of (Siganus canaliculatus). Pro. $1^{\text {st }}$ Int. Symp. On Aquacult. Technol. \& Invest. Opport. Ministry of Agric \& Water Riyadh Saudi Arabia: 109-117.
77. EI-Meligi UAZE (2003) Studies on production of marine fish in North Sinai. M.Sc., Fac. Environ. Agric. Sci., Suez-Canal Uni.

78. Yufera M, Fernandez-Diaz C, Pascual E (1995) Feeding rates of gilthead seabream (Sparus aurata), larvae on microcapsules. Aquacult 134: $257-268$.

79. El-Sayed AM (2002) Effects of density and feeding levels on growth and feed efficiency of Nile tilapia (Oreochromis niloticus L.) fry. Aquacult Res 33: 621-626.

80. Ghousia B, Shantha $V(2001)$ Carbofurantoxicity on total lipids and free fatty Acids in breathing fish during exposure and cessation of exposure- In vivo. Environ Monito \& Assessment 70: 233-239. 